Taphonomy and abundance of birds from the Lower Eocene Fur Formation of Denmark

Dyke, Gareth; Lindow, Bent Erik Kramer

Published in:

Geological Journal

DOI:

10.1002/gj.1150

Publication date:

2009

Document version

Publisher's PDF, also known as Version of record

Citation for published version (APA):

Dyke, G., \& Lindow, B. E. K. (2009). Taphonomy and abundance of birds from the Lower Eocene Fur Formation of Denmark. Geological Journal, 44(3), 365-373. https://doi.org/10.1002/gj.1150 


\title{
Taphonomy and abundance of birds from the Lower Eocene Fur Formation of Denmark
}

\author{
GARETH DYKE ${ }^{1 *}$ and BENT LINDOW ${ }^{2}$ \\ ${ }^{1}$ School of Biology and Environmental Science, University College Dublin, Dublin, Ireland \\ ${ }^{2}$ Geological Museum, Natural History Museum of Denmark, Copenhagen K, Denmark
}

\begin{abstract}
The pattern, pace and extent of the evolutionary radiation of modern birds (Neornithes) by the end-Cretaceous (65 Ma) has long been debated. Well-dated, taphonomically understood and phylogenetically constrained fossil birds from both sides of the Cretaceous-Paleogene (K-Pg) boundary are required to quantify the shape of this radiation, but have largely been lacking. Here we report on a large collection of fossil birds from the Lower Eocene of Denmark ( ca. $54 \mathrm{Ma}$ ) that includes three-dimensionally preserved, articulated specimens from carbonate concretions as well as skeletal imprints and feathers. These birds are from a marine diatomite sequence (the Fur Formation), a low-energy deep-water preservational environment unique to the Cretaceous and Paleogene avian fossil record. We present taphonomic and palaeoecological information gleaned from these birds that in combination with phylogenetic data have implications for unravelling avian survivorship across the K-Pg boundary as well as for the pattern of the neornithine evolutionary radiation. Copyright (C) 2009 John Wiley \& Sons, Ltd.
\end{abstract}

Received 21 June 2008; accepted 7 January 2009

KEY WORDS Aves; taphonomy; survival; evolution

\section{INTRODUCTION}

The pattern and timing of the evolutionary radiation of modern birds (clade Neornithes) has been debated for more than 20 years. The history of this lineage - that includes all the living, or modern birds and their extinct and fossil relatives - is a key focus in several areas of palaeontology and evolutionary biology: the discrepancy between early molecular dates and late fossil dates of divergence of the modern orders, the role of the end-Cretaceous $(\mathrm{K}-\mathrm{Pg})$ mass extinction in re-setting bird evolution and the quality of the avian fossil record (Cooper and Penny 1997; Bleiweiss 1998; Benton 1999; Dyke 2001; Feduccia 2003; Dyke and van Tuinen 2004; Fountaine et al. 2005; Ericson et al. 2006; Dyke et al. 2007). Several questions remain unresolved (Figure 1): how deep into the Cretaceous do the extant lineages extend? Did many—or all—of the modern clades of birds cross the K-Pg boundary before radiating explosively in the Paleocene and Eocene? How many pulses to the modern avian radiation can be identified in the fossil record? What kind of environments did birds inhabit at the time of the K-Pg transition?

Molecular clock-based dates for neornithine divergences markedly contrast with the known fossil record-while evidence from molecules infers almost all divergences deep in the Cretaceous, there is little convincing fossil

* Correspondence to: G. Dyke, School of Biology and Environmental Science, University College Dublin, Belfield, Dublin 4, Ireland.

E-mail: gareth.dyke@ucd.ie 


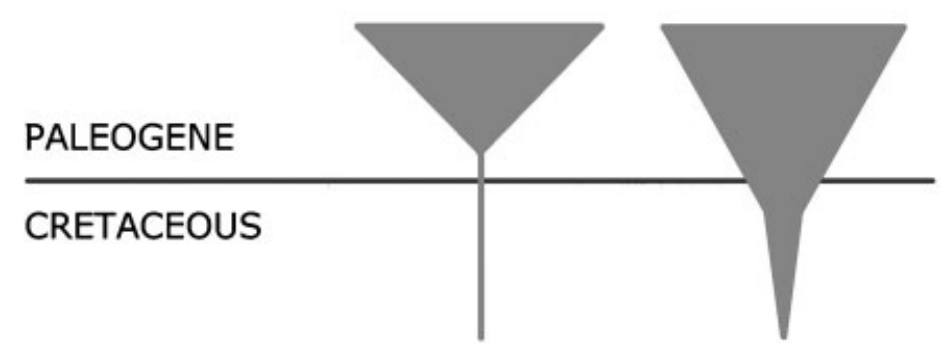

Figure 1. The two competing end-member hypotheses to explain the shape of the evolutionary radiation of modern birds (Neornithes): left side, 'explosive' avian radiation in the early Paleogene (Paleocene and Eocene); right side, bulk of diversification occurs in the Cretaceous, prior to the $\mathrm{K}-\mathrm{Pg}$ extinction.

evidence for modern birds prior to the base of the Paleogene (Dyke 2001; Dyke and van Tuinen 2004; van Tuinen et al. 2006).

Because of the almost total absence of well-preserved fossil material close to, or within, the neornithine radiation from the Cretaceous (Dyke and van Tuinen 2004; Clarke et al. 2005; Tambussi and Acosta Hospitaleche 2007), focus has been placed on the numerically much richer early Paleogene record as a tool for understanding the pattern of modern avian evolution (Dyke 2001). A series of key deposits of Paleocene and early to mid Eocene age has been documented across Europe and North America (Dyke and van Tuinen 2004; Mayr 2005; Lindow and Dyke 2006; Bertelli et al. 2009), but the fossils they contain are typically disarticulated or flattened (or both) and thus cannot yield adequate morphologic information for phylogenetic analysis. To date, no collection of fossil neornithines from a single geological unit has been critically evaluated in terms of specimen taphonomy, their stratigraphic distribution or the phylogenetic placement of taxa in an attempt to elucidate the base of the modern avian radiation. An accumulation of fossil birds, preserved within a small time interval, would allow precise dating of the minimum ages of phylogenetic divergences - a definitive measure of both the extent and pace of the neornithine evolutionary radiation.

One such accumulation comprises the fossil birds from the Lower Eocene Fur Formation of Denmark (Figure 2) which add critical new data bearing on modern avian evolutionary dynamics. Over a 100 Danish fossil specimens are known (as shown in the supplementary data of Appendix 1), commonly three-dimensionally preserved with

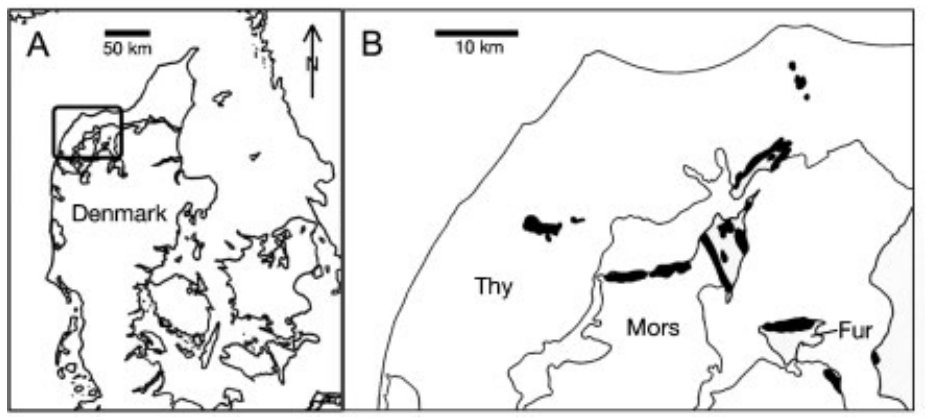

Figure 2. Map of western and central Denmark (A) to show the location of the Fur Formation and associated localities (B) (from Lindow and Dyke 2006). 


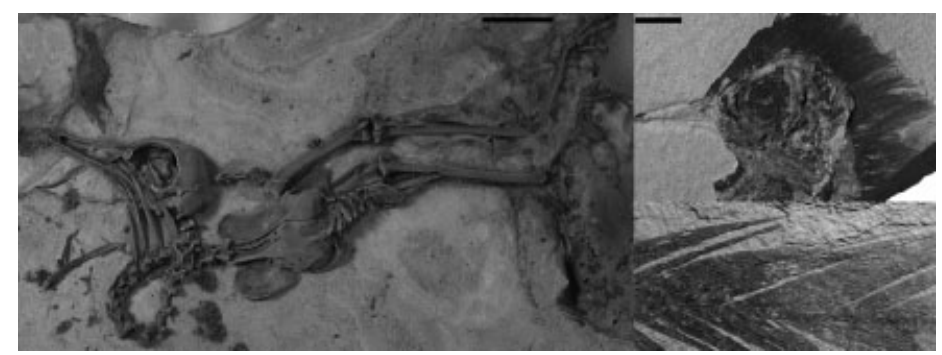

Figure 3. A selection of the fossil bird remains that are known to-date from the Fur Formation of Denmark, left: a three-dimensionally preserved 'shorebird' (Charadriiformes: Lindow and Bertelli in prep.) (scale is $20 \mathrm{~mm}$ ); right: head of a small 'landbird' with associated soft tissues (including head feathering) (scale is $10 \mathrm{~mm}$ ); one of the many avian feathers known from this site.

skeletal elements in articulation (Figure 3), and have been well dated (Figure 4). The Fur Formation birds also often have soft tissue (feathers, skin and scales) remaining (Figure 3) (Appendix 1), and have been increasingly wellconstrained phylogenetically (Dyke et al. 2004; Lindow and Dyke 2006; Bertelli et al. 2009).

In this paper, we present the geological background to the Fur Formation, describe the skeletal taphonomy of the known fossil birds and discuss their significance both to the Eocene fossil record and for reconstructing the shape and pace of the modern avian evolutionary radiation. The Fur Formation birds are important because they represent the oldest accumulation of fossil modern avians for which taphonomic and phylogenetic control are available. Thus we add the available fossils to a comprehensive data set of Paleocene and Eocene birds, and show that their depositional context is unique to the K-Pg avian record: an offshore marine diatomite sequence. By far the majority of Paleogene fossil birds known to date are from marginal marine and freshwater sequences (Dyke et al. 2007).

\section{GEOLOGICAL BACKGROUND}

Sediments of the Fur Formation crop out in northwest Jutland, Denmark (Figure 2), and comprise at least a $60 \mathrm{~m}$ thickness of marine diatomite (Pedersen and Surlyk 1983) interbedded with more than 170 layers of volcanic ash from volcanic eruptions during the opening of the Norwegian-Greenland Sea (the North Atlantic Magmatic Province) in the earliest Eocene (Larsen et al. 2003) (Figure 4). The Fur Formation is Early Eocene in ageconfirmed by ${ }^{39} \mathrm{Ar} /{ }^{40} \mathrm{Ar}$ dates of 54.5 and $54.0 \mathrm{Ma}$ obtained from two ash layers (Chambers et al. 2003) and by the presence of the Paleocene/Eocene boundary in the underlying Stolleklint Clay Member of the Ølst Formation (Heilmann-Clausen and Schmitz 2000). Sediments were deposited in a region of intensive local upwelling in the North Sea Basin; nutrient-rich bottom water resulted in extraordinary blooms of diatoms (Pedersen and Surlyk 1983). Sedimentation of their tests formed a fine-grained diatomite sediment consisting of 45-65\% diatoms, 30$45 \%$ clay minerals and approximately $10 \%$ volcanic dust (Pedersen et al. 2004). Because the formation was deposited at water depths below the storm wave-base under anoxic or slightly dysoxic bottom conditions that did not persist upwards, well-preserved, articulated vertebrate fossils, including birds, are relatively common (Pedersen and Surlyk 1983; Bonde 1987). Within certain horizons calcareous carbonate concretions occur, sometimes in more-or-less continuous layers (Pedersen and Surlyk 1983). X-ray diffraction analysis shows the concretions consist exclusively of low $\mathrm{Mg}$-calcite and the overall $\mathrm{CaCO}_{3}$-content is $70-90 \mathrm{wt} \%$ and $\delta^{13} \mathrm{C}$-values of -20 to $-16 \%$ indicate that most of the carbonate has a bacterial origin (Pedersen and Buchardt 1996). The concretions nucleated in the sea-floor sediment, sometimes around fossils as nucleation centres for the limestone, a relatively short time after deposition (Pedersen and Buchardt 1996).

Although fossil birds have been collected from a number of different localities and horizons within the outcrop area of the Fur Formation, they all derive from the same depositional environment; changes in bottom conditions and oxygen levels occurred simultaneously across the depositional basin (Pedersen and Surlyk 1983). 


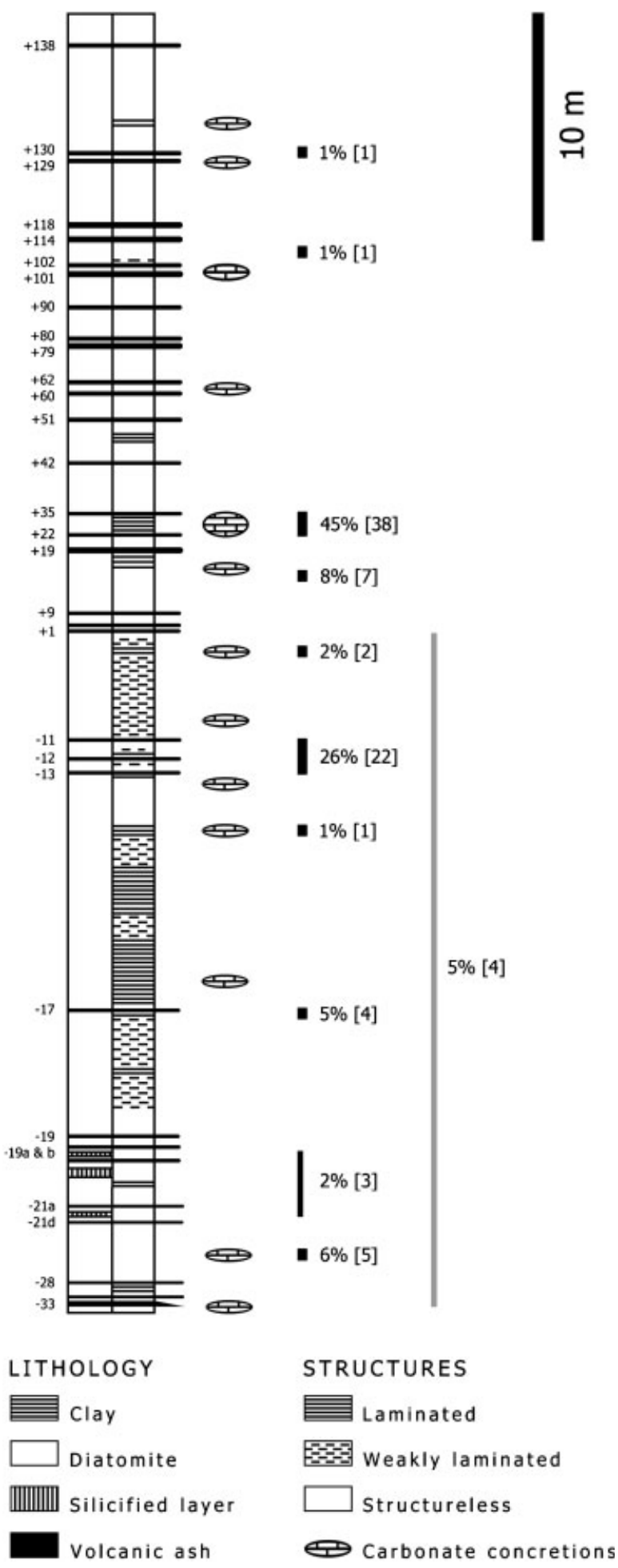

Figure 4. Stratigraphic section of the Fur Formation to show the positions of ash beds, horizons containing concretions and the provenance of fossil birds. Numbers of bird specimens are given in brackets alongside proportion (\%) of entire known collection. 


\section{METHODS}

\subsection{Collection analysis}

One hundred seventy-two fossil bird specimens are currently known from the Fur Formation of which more than 40\% are isolated feathers (Appendix 1). Data for these specimens were collated, including taxonomic information, type and mode of preservation, degree of skeletal completeness and stratigraphic and phylogenetic placement (where available). Precise stratigraphic provenance is known for more than 50\% of the specimens (Lindow 2007). Since the Fur Formation birds are key additional data points documenting the extent of the modern avian radiation by the Early Eocene, we have added them to a comprehensive data set of named taxa from the Paleogene (Paleocene and Eocene; $N=132$; Dyke et al. 2007) (Figure 5A) (as shown in the supplementary data of Appendix 2).

\subsection{Quantitative taphonomy}

Building on an initial census of the Fur Formation birds, including all isolated feathers (Kristoffersen 2002), we have documented the mode of preservation of all skeletal material $(N=108$; Appendix 2$)$ and coded 'degree-ofdisarticulation' following Davis and Briggs (1998) (Figure 5B). These workers described an idealized disarticulation sequence for avian carcasses comprising 11 stages based on actual observations of experimentally degraded carcasses of modern birds (Table 1). Davis and Briggs (1998) also included disarticulation data from four fossil bird-bearing deposits ranging in age from Jurassic (Solnhofen Limestones, Germany; $140 \mathrm{Ma}$ ) to Eocene (Green River Formation, Wyoming; Messel oilshales, Germany; La Meseta Formation, Antarctica; 55-50 Ma). Results - compared with decaying birds in modern comparable sedimentary situations — demonstrated a grade of increasing disarticulation from protected (Solnhofen) through to higher-energy sedimentary environments (La Meseta); unsurprisingly bird carcasses exposed to higher energy regimes are relatively more disarticulated that those experiencing less energy (Figure 5B). Furthermore, since the analysis of Davis and Briggs (1998), additional material of Archaeopteryx from the Solnhofen Limestone has been recovered (Maüser 1997; Wellnhofer and Röper 2005; Mayr et al. 2007). We included this material in the comparative analysis and assigned it to the relevant decay

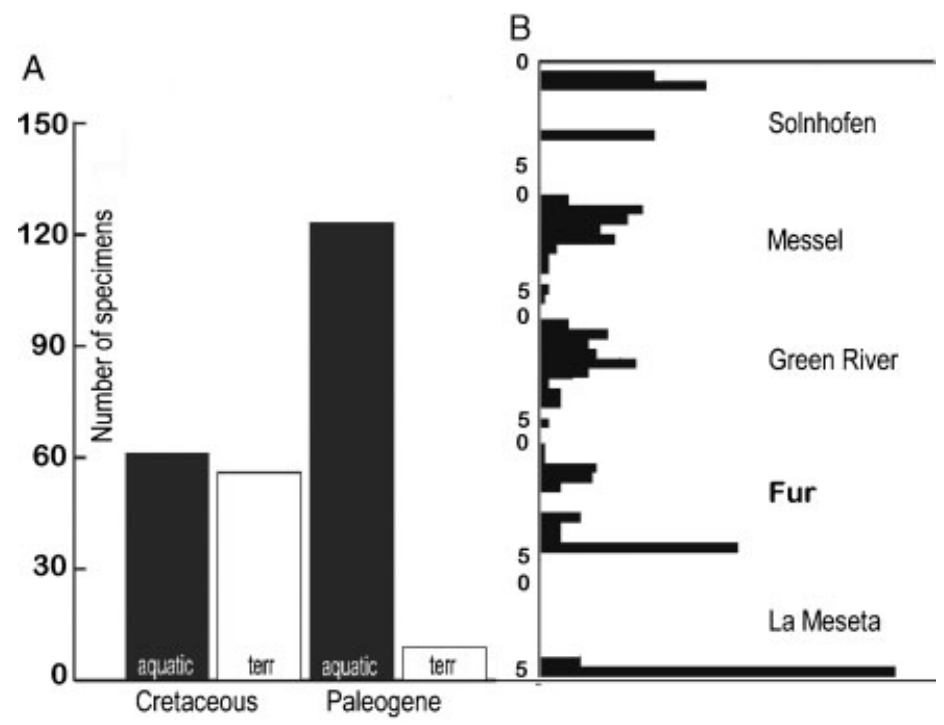

Figure 5. Avian preservation and taphonomy. (A) Numbers of fossil specimens found in aquatic and terrestrial (terr) sediments in the Mesozoic and Paleogene. Numbers of fossil birds known from aquatic and terrestrial environments are significantly different between the Mesozoic and Paleogene $\left(\chi^{2}=54.17, \mathrm{df}=1, \mathrm{p}<0.001\right)$. Only $7 \%$ of fossil specimens are found in terrestrial sediments in the Paleogene (data presented in Appendix 2). Bar chart from Dyke et al. (2007). (B) Bar charts showing stages of skeletal disarticulation (Davis and Briggs 1998) seen in collections of fossil birds from a range of well-known localities (see text for details of this qualitative analysis). 
Table 1. Decay stages for bird carcasses from Davis and Briggs (1998)

\begin{tabular}{ll}
\hline Decay stage & Characteristics \\
\hline 1 & Complete with soft tissues \\
2 & Complete, soft tissues except feathers lost \\
$3 \mathrm{a}$ & Skull and/or cervical vertebrae lost \\
$3 \mathrm{~b}$ & Legs detached from synsacrum \\
$3 \mathrm{c}$ & Pectoral girdle detaches from thorax \\
$3 \mathrm{~d}$ & Thorax and synsacrum detaches from each other \\
$3 \mathrm{e}$ & Thoracic vertebrate and ribs disarticulate from each other \\
$3 \mathrm{f}$ & Leg elements disarticulate from each other \\
$3 \mathrm{~g}$ & Shoulder girdle elements disarticulate from each other \\
4 & Disarticulated, elements still associated \\
5 & Disarticulated in isolated elements \\
\hline
\end{tabular}

stages through studies of the pertinent literature. Davis and Briggs (1998), however, did not interpret their results in the context of avian survivorship across the K-Pg boundary or sample a low-energy marine depositional environment, as recorded by the Fur Formation.

\section{TAPHONOMY AND ENVIRONMENT OF PRESERVATION}

\subsection{Skeletal taphonomy}

The majority of the Fur Formation fossil birds are body fossils (58\%), preserving bone (Figure 3; left) and/or soft tissues, such as feathers and scales (Figure 3; right) (Appendix 1). The remainder are preserved as imprints (compressions) in the fine-grained diatomite (Kristoffersen 2002). Thus, two end-member modes of preservation can be discerned: fossil are preserved in three dimensions within carbonate concretions or are preserved as imprints in diatomite. Although these imprinted fossils are often slightly flattened (Figure 3), the sediment is fine-grained enough to allow details to be picked out on a 1/20 mm-scale (Lindow and Dyke 2006, 2007). Imprints of feathers and soft tissue are common in the Fur Formation; as mentioned above around $40 \%$ of all the bird fossils from the formation are carbonized compressions of lone feathers (Figure 3; bottom right) or feather imprints in life position with respect to bones (Figure 3; top right). Fossil remains from within the carbonate concretions are usually threedimensionally preserved as the hard concretions protected their contents from compaction (Pedersen and Surlyk 1983); a critical characteristic if they are to be included in phylogenetic analyses (Bertelli et al. 2009).

Because of the low-energy environment of preservation, combined with typical fossilization within concretions, the bulk of the Fur Formation birds exhibit low degrees of disarticulation (Figure 5B). Fossils are both taphonomically distinctive and record a different palaeoenvironment than known from elsewhere in the Paleocene and Eocene (Lindow and Dyke 2006): the vast majority of fossil birds of this age are body fossils from terrestrial lake environments (e.g. Messel, Green River Formation) or from near-shore sequences (La Meseta Formation, London Clay Formation) (Dyke et al. 2007). Nevertheless, compared to other Lower Eocene sites (Messel, Green River Formation), the Fur Formation contains very few specimens coded as 'least disarticulated' (stages 1 and 2; Davis and Briggs 1998). Most known Eocene sites comprise more than 90\% single bones (Mlíkovský 2002).

\subsection{Stratigraphic distribution}

Fur Formation fossil birds are concentrated within distinct horizons that occur in the middle and lower parts of the formation (Figure 4). The majority of specimens derive from just two levels: one encompassing ash layers +25 to +30 (carbonate concretion level 'E' of Breiner 1972), and another encompassing ash layers -11 to -13 (Figure 4). Such localized preservation reflects changes in ocean bottom conditions - the lower and middle parts of the formation are known to have been lower in oxygen, inhibiting the activities of scavengers and thus bioturbation. In the upper part of 
the formation above ash layer +30 , where far less fossils are preserved, bottom conditions improve; this is reflected in an increase in the degree of bioturbation and recorded trace fossils (Pedersen and Surlyk 1983).

The stratigraphic distribution of fossils (Figure 4) shows that birds are common only at certain levels within the Fur Formation - characterized by both low $\mathrm{O}_{2}$ and abundant ash layers. One factor alone cannot explain this selective preservation, however, because low $\mathrm{O}_{2}$ bottom conditions characterize the well-laminated sequence between ash layers -13 and -17 where fossil birds are entirely absent (Figure 4).

Interplay between the effects of volcanic ash deposition and low $\mathrm{O}_{2}$ bottom conditions thus likely contributed to the preservation of the Fur Formation fossil birds, perhaps contributing to an environmental lag effect. This argument could be further tested by use of the fossil fishes known from this deposit; these taxa should exhibit the same taphonomy but a markedly different depositional history. However, ash fall deposition alone can be ruled out as an immediate factor causing the death of most of the Fur Formation birds, as few of them are preserved in direct contact with these layers (Figure 4).

\subsection{Preservation environment}

The preservation environment of the Fur Formation - a marine diatomite — is unique to the Paleogene fossil record of birds (Dyke et al. 2007). Adding the Danish specimens to a comprehensive data set of Paleocene and Eocene birds (65-49 Ma; Dyke et al. 2007; Appendix 2) shows that, although the bulk of sediments yielding fossil avians from the Paleocene are aquatic, these sedimentary environments are most often either marginal marine or lacustrine (Figure 5A). This is due to taphonomic bias: we can rule out relative preservation potential as a factor influencing these data because older birds known from the Mesozoic (146-65 Ma), where there are higher volumes of aquatic sediments (Fara 2002), have been recorded across all kinds of environments (Fountaine et al. 2005; Dyke et al. 2007) (Figure 5A). There is no reason to expect that Paleogene birds were any more or less, prone to fossilization than their older Mesozoic counterparts. Also of relevance to this question is the fact that global sea level ('base level') is known to have fallen from the Cretaceous into the Paleogene (Fara 2002). This could have lead either to an overall increase in the available volume of 'terrestrial' rock compared to marine or alternatively could explain the rarity of birds in terrestrial environments because these settings are less commonly preserved. In any case, it remains possible that the simple presence of more birds in aquatic environments in the aftermath of the $\mathrm{K}-\mathrm{Pg}$ event is independent of preservation potential. Dyke et al. (2007) interpreted this result as indicative simply of the presence of more birds living in aquatic environments in the $\mathrm{K}-\mathrm{Pg}$ aftermath than present during the latter stages of the Cretaceous.

The birds collected from the Fur Formation sediments, however, do not represent a 'marine' avifauna. The anatomy and phylogenetic placement of only two taxa are consistent with a near-shore or sea-going ecology (e.g. Charadriiformes; Bertelli et al. 2009). Closer study of the specimen referred to 'Pelecaniformes' n. gen. et sp. by Dyke and Lindow (2006) has revealed it to be, in fact, a new genus and species of galliform bird (Personal Observation, Lindow, 2008). All other specimens clearly have a more terrestrial provenance (Dyke and Lindow 2006). Small 'landbirds' - swifts (Apodiformes) and mousebirds (Coliiformes) — although relatively abundant within the sequence were almost certainly not living out at sea. None of the fossils shows signs of being re-worked into the Fur Formation sediments subsequent to death and fossilization.

\section{DIVERSIFICATION OF MODERN BIRDS}

The more than 160 specimens of fossil birds collected to date from the Fur Formation include at least 30 taxa representing 13 clades of Neornithes (Lindow and Dyke 2006). Taxonomic identification of these specimens has been based on phylogenetic analysis - either the fossils have been included within matrices alongside their extant counterparts, or they have been identified via direct comparisons with other Paleogene taxa that have been already evaluated using cladistic phylogenetic methods (Dyke et al. 2004; Lindow and Dyke 2006; Bertelli et al. 2009). A recent morphological character-rich phylogenetic hypothesis encompassing extant Neornithes recognised 33 'ordinal-level' clades (Livezey and Zusi 2007). Fossil birds from the Fur Formation include representatives of 11 of these higher-level clades; not only taxa inferred to belong to basally diverging lineages (Lithornithiformes, 
Galliformes) but also representatives of crownward clades such as Apodiformes, Coliiformes and Coraciiformes (Dyke et al. 2004; Lindow and Dyke 2006).

It has long been argued that fossil modern birds, when placed confidently within phylogenetic hypotheses, provide the only definitive evidence for the minimum divergence age of that clade (Bleiweiss 1998; Dyke 2001). Molecular clock-based estimates for clade divergence, on the other hand, are indirect at best and are subject to assumptions of rate constancy through time (Dyke and van Tuinen 2004; Ericson et al. 2006). We have conclusive evidence, based on fossils preserved in deposits such as the Fur Formation, for the phylogenetic extent of the radiation of Neornithes by the Early Eocene, 54 Ma.

In the preceding Paleocene epoch a number of neornithine taxa are known, although the lack of a good taphonomic window means that few fossils are preserved as even remotely complete specimens. Nonetheless, the following groups have been described with certainty: palaeognathous Lithornithidae (Houde 1988; Mayr 2007), anseriform Gastornithidae (Buffetaut 1997; Mayr 2007) and Presbyornithidae (Olson 1994; Benson 1999), Cariamae (Mayr 2007), Phorusrhacidae (Alvarenga and Höfling 2003), Messelornithidae (Mourer-Chauviré 1995), Odontopterygiformes (Harrison 1985; Bourdon 2005; Bourdon et al. 2005), Strigiformes (Rich and Bohaska 1976; Mourer-Chauviré 1994; Mayr 2007). In addition, hard evidence in the shape of the presence of undoubted anseriforms in the latest Cretaceous implicates the existence of at least three other lineages of Neornithes in the Cretaceous: Galliformes (the sister taxon of Anseriformes); Neoaves (the sister taxon of Galloanserae) and Palaeognathae (the sister taxon of Neognathae) (Clarke et al. 2005). Finally, recent well-resolved molecular phylogenies using a wide array of genomic sampling and calibration by the use of phylogenetically welldocumented and well-constrained fossils indicate that while some neoavian lineages were present in the Late Cretaceous, the main higher-level diversification phase within the clade took place during the Paleocene, after the K/T-boundary (Ericson et al. 2006; Brown et al. 2008).

However, the veracity of this pattern of temporally disparate origin and diversification of the modern avian lineages will remain unknown until deposits with suitable taphonomic environments capable of preserving birds are discovered for the late Cretaceous and Paleocene epochs.

\section{ACKNOWLEDGEMENTS}

We thank Sara Bertelli, Luis Chiappe, Gilles Cuny, Henrik Madsen, Dave Harper and Sten Lennart Jakobsen for their help with this project and Maria McNamara (UCD) for reviewing an early version of this paper. We are also grateful for the comments of two anonymous reviewers that greatly improved the clarity of this study, supported by grants from IRCSET (2004/ES0009) and NSF (DEB-0454856).

\section{REFERENCES}

Alvarenga HMF, Höfling E. 2003. Systematic revision of the Phorusrhacidae (Aves: Ralliformes). Papéis Avulsos de Zoologia 43: 55-91. Benson RD. 1999. Presbyornis isoni and other Late Paleocene birds from North Dakota. Smithsonian Contributions to Paleobiology 89: 253259.

Benton MJ. 1999. Early origins of modern birds and mammals: molecules vs. morphology. BioEssays 21: $1043-1051$.

Bertelli S, Lindow BEK, Dyke GJ, Chiappe LM. 2009. A well-preserved 'charadriiform-like' fossil bird from the Lower Eocene Fur Formation of Denmark. Palaeontology 52: in press.

Bleiweiss R. 1998. Fossil gap analysis supports early Tertiary origin of trophically diverse avian orders. Geology 26: $323-326$.

Bonde N. 1987. Moler-Its Origin and Its Fossils Especially Fishes. Skamol: Skarrehage Molerværk A/S: Nyk øbing Mors, Danmark.

Bourdon E. 2005. Osteological evidence for sister group relationship between pseudo-toothed birds (Aves: Odontopterygiformes) and waterfowls (Anseriformes). Naturwissenschaften 92: 586-591.

Bourdon E, Boya B, Iarochène M. 2005. Earliest African neornithine bird: a new species of Prophaethontidae (Aves) from the Paleocene of Morocco. Journal of Vertebrate Paleontology 25: 157-170.

Breiner M. 1972. Moleret i Limfjorden. Fur Museum: Nederby.

Brown JW, Rest JS, García-Moreno J, Sorenson MJ, Mindell DP. 2008. Strong mitochondrial DNA support for a Cretaceous origin of modern avian lineages. BioMed Central Biology 6: 1-18. DOI: 10.1186/1741-7007-6-6

Buffetaut E. 1997. New remains of the giant bird Gastornis from the Upper Paleocene of the eastern Paris Basin and the relationships between Gastornis and Diatryma. Neues Jahrbuch für Geologie und Paläontologie Monatshefte 1997: 179-190. 
Chambers LM, Pringle M, Fitton G, Larsen LM, Pedersen AK, Parrish R. 2003. Recalibration of the Palaeocene-Eocene boundary (P-E) using high precision U-Pb and Ar-Ar isotopic dating. Geophysical Research Abstracts 5, EGS-AGU-EUG Joint Assembly, Nice, 6th-11th April 2003, 9681-9682.

Clarke JA, Tambussi CP, Noriega JI, Erickson GM, Ketcham RA. 2005. Definitive fossil evidence for the extant avian radiation in the Cretaceous. Nature 433: 305-308.

Cooper A, Penny D. 1997. Mass survival of birds across the KT-boundary: molecular evidence. Science 275: 1109-1113.

Davis PG, Briggs DEG. 1998. The impact of decay and disarticulation on the preservation of fossil birds. Palaios 13: 3-13.

Dyke GJ. 2001. The evolution of birds in the early Tertiary: systematics and patterns of diversification. Geological Journal 36: 305-315.

Dyke GJ, van Tuinen M. 2004. The evolutionary radiation of modern birds (Neornithes): reconciling molecules, morphology and the fossil record. Zoological Journal of the Linnaean Society 141: 153-177.

Dyke GJ, Nudds RL, Benton MJ. 2007. Birds across the KP boundary. The Auk 124: 339-341.

Dyke GJ, Waterhouse DM, Kristoffersen AV. 2004. Three new landbirds from the early Paleogene of Denmark. Bulletin of the Geological Society of Denmark 51: 47-56.

Ericson GP, Anderson CL, Britton T, Elzanowski A, Johansson US, Kallersjö M, Ohlson JI, Parsons TJ, Zuccon D, Mayr G. 2006. Diversification of Neoaves: integration of molecular sequence data and fossils. Biology Letters 2: 543-547.

Fara E. 2002. Sea-level variations and the quality of the continental fossil record. Journal of the Geological Society 159: 489-491.

Feduccia A. 2003. 'Big bang' for Tertiary birds? Trends in Ecology and Evolution 18: 172-176.

Fountaine TMR, Benton MJ, Dyke GJ, Nudds RL. 2005. The quality of the fossil record of Mesozoic birds. Proceedings of the Royal Society of London Series B (Biological Sciences) 272: 289-294.

Harrison CJO. 1985. A bony-toothed bird (Odontopterygiformes) from the Palaeocene of England. Tertiary Research 7: $23-25$.

Heilmann-Clausen C, Schmitz B. 2000. The late Paleocene thermal maximum $\delta 13 \mathrm{C}$ Denmark? Geologiska Föreningen $i$ Stockholm Förhandlinger 122: 70.

Hoch E, Pedersen SS. 1983. En gammel fugl. VARV 4: 99-107.

Houde P. 1988. Paleognathous birds from the Early Tertiary of the Northern Hemisphere. Publications of the Nuttal Ornithological Club 22: 1148.

Kristoffersen AV. 2002. The avian diversity in the latest Paleocene-earliest Eocene Fur Formation: a synopsis. Unpublished Ph.D.Thesis, Geological Institute University of Copenhagen.

Larsen LM, Fitton JG, Pedersen AK. 2003. Paleogene volcanic ash layers in the Danish Basin: compositions and source areas in the North Atlantic Igneous Province. Lithos 71: 47-80.

Lindow BEK. 2007. En stratigrafisk og tafonomisk analyse af fossile fugle og fjer fra Fur Formationen. Geologisk Tidsskrift 2007 : 15-17.

Lindow BEK, Dyke GJ. 2006. Bird evolution in the Eocene: climate change in Europe and a Danish fossil fauna. Biological Reviews of the Cambridge Philosophical Society 81: 1-16.

Lindow BEK, Dyke GJ. 2007. A small galliform bird from the Lower Eocene Fur Formation. Bulletin of the Geological Society of Denmark 55: 59-63.

Livezey BL, Zusi RL. 2007. Higher-order phylogenetics of modern birds (Theropoda, Aves: Neornithes) based on comparative anatomy. II. Analysis and discussion. Zoological Journal of the Linnean Society 149: 1-95.

Maüser M. 1997. Der achte Archaeopteryx. Fossilien 14: 156-157.

Mayr G. 2005. The Paleogene fossil record of birds in Europe. Biological Reviews of the Cambridge Philosophical Society 80: 515-542.

Mayr G. 2007. The birds from the Paleocene fissure filling of Walbeck (Germany). Journal of Vertebrate Paleontology 27: $394-408$.

Mayr G, Pohl B, Hartman S, Peters DS. 2007. The tenth skeletal specimen of Archaeopteryx. Zoological Journal of the Linnean Society 149: 97-116.

Mlíkovský J. 2002. Cenozoic Birds of the World. Part 1: Europe. Ninox Press: Praha.

Mourer-Chauviré C. 1994. A large owl from the Palaeocene of France. Palaeontology 37: 339-348.

Mourer-Chauviré C. 1995. The Messelornithidae (Aves: Gruiformes) from the Paleogene of France. Courier Forschungsinstitut Senckenberg 181: $95-105$.

Olson SL. 1994. A giant Presbyornis (Aves: Anseriformes) and other birds from the Paleocene Aquia Formation of Maryland and Virginia. Proceedings of the Biological Society of Washington 107: 429-435.

Pedersen GK, Buchardt B. 1996. The calcareous concretions (cementsten) in the Fur Formation (Paleogene, Denmark): isotopic evidence of early diagenetic growth. Bulletin of the Geological Society of Denmark 43: 78-86.

Pedersen GK, Pedersen SAS, Steffensen J, Pederson CP. 2004. Clay content of a clayey diatomite, the Early Eocene Fur Formation, Denmark. Bulletin of the Geological Society of Denmark 51: 159-177.

Pedersen GK, Surlyk F. 1983. The Fur Formation, a late Paleocene ash-bearing diatomite from northern Denmark. Bulletin of the Geological Society of Denmark 32: 43-65.

Rich PV, Bohaska DJ. 1976. The World's Oldest Owl: a new strigiform from the Paleocene of Southwestern Colorado. Smithsonian Contributions to Paleobiology 27: 87-93.

Tambussi C, Acosta Hospitaleche C. 2007. Antarctic birds (Neornithes) during the Cretaceous-Eocene times. Revista de las Asociatión Geológica Argentina 62: 604-617.

van Tuinen M, Stidham TA, Hadly EA. 2006. Tempo and mode of modern bird evolution observed with large-scale taxonomic sampling. Historical Biology 18: 209-225.

Wellnhofer P, Röper M. 2005. Das neunte Archaeopteryx-exemplar von Solnhofen-Zum Gedenken an John H. Ostrom. Archaeopteryx 23: 3-21.

Scientific editing by Dave Harper 